\title{
EVALUASI CAPAIAN PELAKSANAAN PROGRAM ASI EKSKLUSIF DI PUSKESMAS OLAK KEMANG KECAMATAN DANAU TELUK KOTA JAMBI TAHUN 2017
}

\author{
Evaluation of the achievement exclusive ASI program implementation at the Olak Kemang Health \\ Center in the Teluk Teluk Subdistrict, Jambi City in 2017
}

Sondang Silvianta ${ }^{1}$, Rd.Halim² ${ }^{2}$ M.Ridwan² .

${ }^{1}$ Program Sarjana Studi Ilmu Kesehatan Masyarakat Universitas Jambi
${ }^{2}$ Ilmu Kesehatan Masyarakat, Fakultas Kesehatan Masyarakat, Universitas Jambi

\begin{abstract}
ABSTRAK
Beberapa negara berkembang angka global ibu menyusui hanya meningkat dengan sangat perlahan selama beberapa dekade terakhir, Sebagian karena rendahnya tingkat menyusui di beberapa negara-negara besar, dan kurangnya dukungan untuk ibu menyusui dari lingkungan sekitar. Air Susu Ibu (ASI) adalah cairan hidup yang mengandung sel-sel darah putih, imunoglobin, enzim dan hormon serta protein spesifik, dan zat gizi lainnya yang diperluas untuk pertumbuhan dan perkembangan anak. Penelitian ini menggunakan jenis penelitian kualitatif dengan pendekatan studi kasus. Responden dalam penelitian ini berjumlah 7 orang. Teknik pengambilan data dengan menggunakan wawancara mendalam, observasi dan telaah dokumen. Hasil penelitian menunjukan bahwa secara input sumber daya manusia (Petugas Konselor) secara kuantitas sudah memenuhi standar, Secara kualitas petugas sudah mengikuti pelayihan konselor ASI, Petugas memiliki beban kerja rangkap. Sarana/prasarana penunjang belum memenuhi standar. Sumber dana belum mencukupi untuk Program ASI Eksklusif. Secara proses pelaksanaan belum terlaksana secara keseluruhan hanya kegiatan sosialisasi yang baru berjalan, Proses Konseling ASI belum memiliki kegiatan pokok. Secara output cakupan program ASI Eksklusif di Puskesmas masih di bawah target SPM hal ini disebabkan pada aspek input pemanfataan sarana/prasarana masih belum terealisasi, Sumber dana yang terbatas dan Puskesmas Olak Kemang belum melaksanakan program kerja pemberdayaan kelompok peduli ASI Eksklusif di wilayah kerja Puskesmas Olak Kemang.
\end{abstract}

Kata Kunci : Evaluasi, ASI Eksklusif, Pelaksanaan Program.

\begin{abstract}
ABSTRACK
Some developing countries global rates of breastfeeding mothers have only increased very slowly over the past few decades, in part because of the low rates of breastfeeding in some large countries, and the lack of support for breastfeeding mothers from the surrounding environment. Exclusive breastfeeding is a living fluid containing white blood cells, immunoglobin, enzymes and hormones and specific proteins, and other nutrients that are extended to the growth and development of children. This research uses qualitative research with a case study approach. Respondents in this study amounted to 7 people. Data collection techniques using in-depth interviews, observation and document review. The results showed that the input of human resources (Counselor Officers) in quantity had met the standards, the quality of the officers had followed the ASI counselor service, the Officer had a double workload. Supporting facilities / infrastructure have not met the standards. Sources of funds are not sufficient for the Exclusive ASI Program. The implementation process has not been carried out as a whole, only the socialization activities that have just started, the ASI Counseling Process does not yet have a main activity. The output of the Exclusive Breastfeeding program coverage in Puskesmas is still below the SPM target, this is due to the fact that the input aspect of the utilization of facilities / infrastructure is still not realized.
\end{abstract}

Keywords : Evaluation, Exclusive breastfeeding, Program Implementation.

Korespodensi : Sondang Silvianta

Email : sondangsilviantaikm@gmail.com 
PENDAHULUAN

World Health Organization (WHO) merekomendasikan anak hanya disusui ASI selama paling sedikit 6 bulan, Makanan padat seharusnya diberikan sesudah anak berusia 6 bulan, dan pemberian ASI dilanjutkan sampai anak berusia dua tahun. Berdasarkan rekomendasi tersebut Pada tahun 2003 pemerintah Indonesia mengubah klasifikaasi usia maksimal pemberian ASI Eksklusif di Indonesia dari 4 bulan menjadi 6 bulan ${ }^{1}$.

Berdasarkan data dari The United Nations Children's Fund (UNICEF) di beberapa negara berkembang angka global hanya meningkat dengan sangat perlahan selama beberapa dekade terakhir, Sebagian karena rendahnya tingkat menyusui di beberapa negaranegara besar, dan kurangnya dukungan untuk ibu menyusui dari lingkungan sekitar. Kamboja berhasil meningkatkan tingkat pemberian ASI eksklusif untuk bayi di bawah 6 bulan secara drastis dari 11,7 persen pada tahun 2000 menjadi 74 persen pada tahun 2010. Pada sisi lainnya, tingkat pemberian ASI eksklusif di Tunisia turun drastis dari 46,5 persen di tahun 2010 menjadi hanya 6,2 persen pada akhir dekade ini. Pemberian ASI Eksklusif di negara Nigeria tidak ada perbaikan selama bertahun-tahun, dan beberapa angka terendah di dunia adalah di Somalia, Chad dan Afrika Selatan ${ }^{2}$.

Tujuan Program ASI Eksklusif yang di rancang oleh pemerintah Indonesia di dalam rencana pembangunan kesehatan menuju Indonesia sehat 2010 adalah meningkatkan sekurang-kurangnya $80 \%$ dari ibu menyusui dapat memberikan ASI secara eksklusif kepada bayinya, sedangkan tujuan program ASI
Eksklusif bagi tenaga kesehatan adalah diperolehnya peningkatan pengetahuan dan kemampuan petugas kesehatan di tingkat Puskesmas dalam upaya meningkatkan penggunaan ASI di masyarakat. Petugas kesehatan diharapkan dapat mendukung keberhasilan menyusui dan bebas dari susu formula ${ }^{3}$.

ASI $\begin{array}{ccr}\text { Keberhasilan Evaluasi Program } \\ \text { Eksklusif }\end{array}$ evektifitas pengelolaan manajemen puskesmas. Keberhasilan Program ASI Eksklusif tidak hanya ditentukan oleh komponen input, tetapi juga kreativitas dan upaya aktif melakukan strategi promosi kesehatan. Kemampuan petugas promkes dinilai kurang sebagai akibat dari penempatan posisi Penyuluh Kesehatan Masyarakat di puskesmas yang tidak sesuai dengan kriteria yang ditetapkan, dan adanya tugas lain selain tugas pokok dan fungsi. Dengan kata lain kebijakan tentang sumber daya manusia penyuluh kesehatan masyarakat belum terlaksana dengan baik ${ }^{4}$.

Indikator keberhasilan program ASI Eksklusif diukur berdasarkan perencananaan, pengorganisasian, dan implementasi program ${ }^{5}$. Berdasarkan Laporan Pencapaian Indikator Kinerja Pembinaan Gizi di Kota Jambi tahun 2016 diperoleh informasi dari 20 puskesmas di Kota Jambi yang terdata, Puskesmas Olak Kemang merupakan puskesmas dengan jumlah bayi yang tidak mendapatkan ASI Eksklusif terendah dengan persentase 0,00 pada semester pertama dan $28,21 \%$ pada semester kedua angka tersebut menunjukan capaian ASI Eksklusisif di Puskesmas Olak Kemang masih dibawah target SPM yang telah di 
tentukan oleh pemerintah sebesar $80 \%$ per wilayah kerja ${ }^{6}$.

\section{METODE}

Penelitian ini menggunakan rancangan penelitian kualitatif dengan strategi pendekatan studi kasus. Penelitian dilakukan untuk menilai komponen Masukan (input),Proses ( proces) dan Keluaran (output). Informan penelitian berjumlah tujuh orang. tiga orang dari Puskesmas Olak Kemang yang terdiri dari Kepala Puskesmas, Pemegang program gizi dan Pemegang program KIA ( Bidan). 4 orang terdiri dari Ibu menyusui ASI Eksklusif. yang diambil dengan teknik purposive sampling dengan pertimbangan informan memiliki informasi yang diperlukan dan terlibat dalam pelaksanaan Program ASI Eksklusif di Puskesmas Olak Kemang. Penelitian di lakukan di Puskesmas Olak Kemang Kota Jambi pada bulan Maret 2018.

Pengumpulan data dengan melakukan telaah dokumen, wawancara mendalam (indepth interview) dan observasi. Telaah dokumen dilakukan untuk mengecek kelengkapan data meliputi sertifikat pelatihan, data kunjungan klien, data kegiatan yang sudah di jalankan sebelumnya data data pencapaian ASI terbaru di Puskesmas Olak Kemang. Wawancara mendalam dilakukan pada informan (kepala puskesmas, pemegang program gizi dan pemegang program KIA) melakukan observasi kelengkapan sarana prasarana dan pelaksanaan konseling menyusui Pengolahan data dilakukan dengan melakukan transkripsi hasil wawancara, menyusun meaning unit, melakukan abstraksi berupa coding, menyusun kategori , menyusun Tema yang telah teridentifikasi dari kumpulan data dirumuskan dan dikelompokkan menjadi suatu variabel.

\section{HASIL DAN PEMBAHASAN}

Pelaksanaan konseling menyusui digambarkan dalam bentuk uraian penjelasan menggunakan logic model meliputi komponen Masukan (Input), proses (proces) dan keluaran (output):

Komponen Input dalam Pelaksanaan Program ASI Eksklusif di Puskesmas Olak Kemang

Aspek Input yanng di teliti terdiri dari 3 hal yaitu SDM (Petugas konseler ASI) yang di nilai secara kuantitas dan kualitas, angaran dana dan sarana/prasarana yang digunakan dalam mendukung program ASI Eksklusif di Puskesmas Olak Kemang . Secara Kuantitas pogram pemberian ASI eksklusif di Puskesmas Olak Kemang mengerahkan seluruh petugas yang bertanggung jawab terhadap program Gizi dan KIA yaitu 2 petugas gizi yang terdiri dari 1 pemegang program yang menjadi penanggung jawab program ASI Eksklusif di Puskesmas Olak Kemang dan 1 asisten ahli gizi.

Berdasarkan hasil penelitian yang telah dilakukan, dijelaskan bahwa petugas yang terlibat dalam pelaksanaan ASI Eksklusif di Puskesmas Olak Kemang berjumlah 2 -3 orang yang terdiri dari kepala puskesmas selaku penangung jawab dan ketua , 1 petugas gizi,1 asisten ahli gizi dan 1 petugas KIA (bidan). Berikut salah satu pernyataan informan:

"...2-3orang yang terlibat kalau untuk kegiatan di lapangan (Informan 1) 
Berdasarkan hasil penelitian yang telah dilakukan, dapatkan bahwa petugas Konseling ASI sudah ditempatkan sesuai tugas pokok dan fungsi dan memiliki tugas rangkap selain pada program ASI Eksklusif seperti pernyataan yang diungkapkan oleh beberapa informan pada saat di lakukan wawancara :

... "Ya pasti ada lah dek, saya megang imunisasi juga. ndak, ada tugas-tugas lain nama nya kita bidan pasti banyak kerjaan lain yang ditanganin" (I-3).

Berdasarkan hasil penelitian yang dilakukan kepada tiga informan dari Puskesmas Olak Kemang mengatakan bahwa sumber dana dalam mendukung pelaksanaan progran ASI Eksklusif di Puskesmas Olak Kemang berasal dari dana BOK dan belum ada bantuan lainnya. Tidak ada pendanaan khusus yang dialokasikan puskesmas untuk konseling menyusui. Konselor hanya menerima gaji bulanan sebagai pegawai negeri sipil dan tidak ada tunjangan khusus bagi konselor menyusui. Hal ini didukung oleh pernyataan informan yang mengatakan bahwa :

.."dana BOK itu di gunakan untuk dana transport petugas di luar gedung jadi untuk di dalam gedung itu tidak menggunakan dana karena itu merupakan salah satu tupoksi dari petugas tersebut" (Informan I-2).

Berdasarkan hasil observasi terhadap kondisi ruang menyusui di Puskesmas Olak Kemang kondisi ruang menyusui minim fasilitas. Ruang Menyusui di Puskemas Olak Kemang berbentuk box (kotak) yang dibatasi oleh tirai/ gorden. Letaknya yang belum srategis karena diletakan pada lantai dua sedangkan ibu melakukan kunjungan dan pelayanan kesehatan di lantai satu, Pencahayaan di ruangan tersebut kurang karena ruangan menyusui diletakan disudut atas ruangan tanpa lampu tambahan didalamnya. Kondisi dalam ruangan belum tertata dengan baik, fasilitas ruang menyusui belum tersedia dan di dalam ruangan dipenuhi oleh tumpukan kasur yang tidak terpakai. Berdasarkan hasil penelitian kepada informan, Puskesmas Olak Kemang sudah memiliki Pojok Laktasi tetapi belum di aktifkan, hal ini didukung oleh pernyataan informan yang menyatakan bahwa :

..."pojok laktasi di puskesmas olak kemang belum di aktifkan kembali, karena terkendala tempat " (Informan I1).

Sarana dan prasarana lain yang dimiliki oleh puskesmas Olak Kemang memiliki seperangkat ASI KIT yang digunakan untuk proses konseling menyusui terhadap ibu. Buku panduan dan leaflet di sediakan di ruang tunggu pelayanan dan dibagikan pada saat sosialisasi sedangkan alat peraga ASI KIT di gunakan pada saat pelatihan/ sosialisasi setiap bulanya. Hal ini di dukung oleh Informan yang mengatakan bahwa:

..."Ada juga punya ASI KIT itu bantuan dari pusat dinas yang kasih kemaren setiap bulan itu kadang kita berikan leaflet, buku bacaan atau ada di tampilkan poster poster tentang ASI Eksklusif itu sendiri" (Informan I-3).

Komponen Proses dalam Pelaksanaan Program ASI Eksklusif di Puskesmas Olak Kemang 
Pelaksanaan Program ASI Eksklusif di Puskesmas Olak Kemang di awali dengan melakukan pendataan sasaran penerima program yang di tunjukan berdasarkan telaah dokumen kunjungan lapangan di Puskesmas Olak Kemang setiap bulan nya. Sasaran yang di maksud adalah Ibu yang mempunyai bayi berusia $0-6$ bulan yang berada di wilayah kerja Puskesmas Olak Kemang. Hal ini didukung oleh pernyataan beberapa informan yang menyatakan bahwa :

..."Ya, setelah di lakukan pendataan sasaran ibu menyusui yang punya bayi 0-6 bulan sudah di lakukan" (Informan $\mathrm{I}-2)$.

Berdasarkan hasil penelitian, puskesmas olak kemang melaksanakan kegiatan sosialisasi setiap bulan untuk mendukung program ASI Eksklusif. Hal ini sesuai dengan pernyataan beberapa informan sebagai berikut :

..." kemudian di lakukan lagi sosialisasi setiap bulan tentang ASI Eksklusif itu untuk meningktakan pengetahuan IbuIbu menyusui seberapa penting ASI Eksklsuif itu” (Informan I-2).

Pelaksanaan konseling ASI di Puskesmas Olak Kemang terkendala belum ada standar pelaksanaan kegiatan yang tersusun secara baku, Kegiatan konseling hanya di lakukan pada saat melakukan pelayanan kesehatan di puskesmas dan digabung dengan kegiatan sosialisasi di lapangan. pelaksanaan konseling ASI terkendala pada belum terbentuknya sarana/wadah untuk melakukan konseling di luar puskesmas seperti belum terebentuknya Kelompok Peduli ASI (KP-ASI) di Wilayah Kerja Puskesmas Olak
Kemang. Hal ini didukug oleh pernyataan informan sebagai berikut :

... "Kalau kegiatan pokok kita belum ada masih di gabungkan semua ke sosialisasi itu, nah ini kita belum ada seharusnya di kegiatan KP-ASI bisa dimasukan, tapi kan KP-ASI belum terbentuk" (Informan I-1).

Berdasarkan hasil penelitian yang sudah di lakukan kepada informan, rendah nya partisipasi masyarakat untuk mengikuti kegiatan menjadi salah satu kendala dalam melaksanakan kegiatan Program ASI Eksklusif di Puskesmas Olak kemang yang didukung dari pernyataan informan sebagai berikut:

..."partisipasi masyarakat nya kurang ,alasanya macam macam lah mau masak, dak sempat”'( Informan I-3)

Berdasarkan wawancara mendalam yang di lakukan kepada informan ibu menyusui di dapatkan informasi bahwa hambatan untuk mengikuti kegiatan sosialisasi adalah kurang nya minat dan motivasi ibu untuk menghadiri sosialisasi dan informasi tentang pelaksanaan kegiatan tersebut yang masih belum merata diterima oleh ibu. Hal tesebut didukung oleh pernyataan informan sebagai berikut :

..."Alasannyo yo kenapo yo dak tau dek sayo samo kurang berminat be dek"(Informan I-7).

Berdasarkan hasil penelitian, pengaruh susu formula menjadi salah satu penyebab rendah nya capaian ASI Eksklusif di Puskesmas Olak Kemang yang di dukung oleh pernyataan informan sebagai berikut :

..."Kebanyakan juga Ibu ini mau yang instan saja, misal nya ASI nya ndak 
keluar langsung aja di kasih nya susu formula" (Informan I-3)

Berdasarkan hasil wawancara mendalam kepada informan ibu menysusi di dapatkan informasi kondisi ibu yang tidak mampu memberikan ASI secara penuh kepada bayi dengan alasan fisik seperti ASI yang tidak lancar/tidak mau keluar membuat ibu memilih memberikan susu tambahan kepada bayi di usia yang belum melewati 6 bulan. Pernyataan tersebut di dukung oleh informan yang menyatakan bahwa :

..."sayo ASI nyo itu tidak mau keluar, anak rewel terus mungkin haus kan jadi terpakso sayo berikan susu bantu"(Informan I-7)

Mayoritas penduduk di wilayah kerja puskesmas olak kemang merupakan penduduk melayu yang masih kental dengan kepercayaan budaya yang bersifat islami. Berdasarkan hasil penelitian pengaruh adat istiadat seperti memberi air zam zam kepada bayi sebagai pengganti ASI masih di temukan, Air zam-zam di anggap sebagai suatu hal yang suci untuk di berikann kepada bayi selain susu fomula dan makanan tambahan lainnya sehingga ibu mengangap dengan memberikan air zam-zam lebih baik sebagai pengganti ASI Eksklusif. . Hal tersebut di dukung oleh pernyataan informan sebagai berikut :

..."mereka mungkin percaya bahwa bayi yang baru lahir di beri air zam zam agar anak nya sehat dan pintar." (Informan I2)

Komponen Keluaran (Output) dalam Pelaksanaan Program ASI Eksklusif di Puskesmas Olak Kemang
Berdasarkan input dan proses tersebut output dari pelaksaan program ASI Eksklusif bisa tergambarkan sudah maksimal atau belum maksimal. Secara realisasi rendahnya output dari pelaksanaan program ASI Eksklusif di Puskesmas Olak Kemang belum tercapai karena terkendala dari external puskesmas seperti pemberdayaan masyarakat untuk mendukung program ASI Eksklusif belum teralisasi dikarenakan beberapa hambatan seperti kurangnya SDM kader dan anggaran dana belum tersedia. Hal tersebut didukung oleh pernyataan Informan sebagai berikut :

..."belum mencapai target,mungkin di usahakan untuk tahun selanjutnya untuk bisa memenuhi target yang sudah di tetapkan, "(Informan I-1)

\section{PEMBAHASAN}

\section{Komponen Input dalam Pelaksanaan Program ASI Eksklusif di Puskesmas Olak Kemang}

Berdasarkan hasil kuantitas SDM Puskesmas Olak Kemang memiliki petugas konsoler berjumlah 4 orang yang terdiri dari Kepala Puskesmas selaku ketua dan penanggung jawab, petugas gizi, asisten ahli gizi dan 1 petugas KIA (Bidan). Seluruh petugas kesehatan yang menjadi petugas konseler ASI sudah mengikuti pelatihan dan memiliki sertifikat. Hal ini sesuai dengan peraturan Kemenkes Nomor 13 Tahun 2003 Tentang Tata Cara Penyedian Fasilitas Menyusui dikatakan bahwa secara kuantitas tidak batasi berapa jumlah minimal konselor ASI di Puskesmas, Semua Tenaga Kesehatan bisa menjadi konselor ASI dengan syarat 
adalah tenaga yang memiliki pengetahuan dan/atau keterampilan mengenai pemberian ASI melalui pelatihan, antara lain konselor menyusui yang telah mendapatkan sertifikat ${ }^{7}$.

Keberhasilan suatu rencana erat kaitannya dengan kemampuan seseorang yang diperoleh dari pendidikan dan pelatihan. Pelatihan merupakan upaya untuk memperbaiki performa pekerja pada suatu pekerjaan. Pelatihan harus mencakup pengalaman belajar, aktivitasaktivitas yang terencana, dan didesain sebagai jawaban atas kebutuhankebutuhan yang berhasil diidentifikasi. Secara ideal pelatihan harus didesain untuk mewujudkan tujuan-tujuan organisasi $^{8}$.

Provinsi Jambi telah mengadakan pelatihan konselor ASI bagi tenaga kesehatan yang bekerja di Puskemas dengan pelaksanaan pelatihan diserahkan kepada tiap-tiap Dinas Kesehatan Kabupaten/Kota. Untuk Puskesmas Olak Kemang pelatihan sudah di lakukan pada tahun 2016 yang diikuti oleh petugas gizi dan bidan. Bidan konselor ASI yang bekerja di Puskesmas Perawatan mempunyai tugas pokok dan tugas tambahan yang sangat kompleks sehingga tidak jarang mengalami kesulitan untuk melaksanakan setiap tugasnya dengan baik dan berdampak terhadap kinerjanya yang tidak maksimal. Kehadiran konselor ASI diharapkan akan dapat mengurangi permasalahan tentang rendahnya dukungan tenaga kesehatan dalam hal pemberian ASI eksklusif. Dengan adanya dukungan, para ibu akan meningkat kepercayaan dirinya dan akan lebih termotivasi untuk terus memberikan ASI.
Kunci keberhasilan suatu program adalah pengelolaan sumber daya manusianya. Organisasi memerlukan SDM yang mau bekerja keras, berpikir kreatif, dan berkinerja unggul. Sumber daya manusia meliputi semua orang yang berstatus sebagai anggota dalam organisasi yang masing-masing memiliki peran dan fungsi. Pada prinsipnya sumber daya manusia adalah satusatunya sumber daya yang menentukan organisasi ${ }^{9}$.

Keterbatasan dana dari Puskesmas

Olak Kemang dalam melakukan kegiatan pemberdayaan dalam bentuk Kelompok Peduli ASI (KP-ASI) diperlukan bantuan swadaya masyarakat. Di dalam program KP-Ibu pihak dinas kesehatan tidak menganggarakan dana karena KP-Ibu yaitu kegiatan pemberdayaan masyarakat yang sebenarnya pendanaan utama adalah swadaya masyarakat itu sendiri. Tetapi saat ini tidak ada KP-Ibu yang mempunyai swadaya masyarakat, sehingga puskesmas memberikan stimulan agar KP-Ibu berjalan. Puskesmas memberikan dana stimulan untuk program KP-Ibu tergantung dari anggaran yang dimiliki setiap puskesmas dan prioritas program KP-Ibu ${ }^{10}$

Kendala yang berkaitan dengan ruang Menyusui di puskesmas Olak Kemang tidak mempunyai sarana pendukung lainnya sebagaimana ditentukan di dalam Persyaratan kesehatan Ruang ASI sebagaimana dimaksud dalam Pasal 9 ayat (2) yang menyatakan tersedianya ruangan khusus dengan ukuran minimal $3 \times 4 \mathrm{~m} 2$ dan/atau disesuaikan dengan jumlah pekerja perempuan yang sedang menyusui ada pintu yang dapat dikunci, yang mudah dibuka/ditutup, lantai 
keramik/semen/karpet,

memiliki ventilasi dan sirkulasi udara yang cukup ${ }^{7}$.

Komponen Proses dalam Pelaksanaan Program ASI Eksklusif di Puskesmas Olak Kemang

Standar pelayanan gizi penyelengaran program ASI Eksklusif komponen proses meliputi Pelatihan PPASI , Pengadaan materi KIE ASI Eksklusif, Pendataan sasaran ASI Eksklusif, Sosialisasi KIE ASI Eksklusif, Pembinaan teknis dan pelaporan Evaluasi. Berdasarkan hasil wawancara pada saaat penelitian diketahui bahwa pelaksanaan kegiatan ASI Eksklusif sudah di lakukan seperti pendataan sasaran, pengadaan materi dan sosialisai ASI Eksklusif kepada ibu menyusui.

Petugas melakukan pendataan sasaran untuk mencari jumlah ibu menyusui di wilayah kerja puskesmas tersebut, kemudian melakukan pengadaan materi pada saat sosialisasi berupa materi sosialisasi di sesuaikan dengan standar materi sosialisasi ASI Eksklusif diantaranya Menjelaskan bahwa standar emas pemberian makanan bayi dan anak usia dini adalah Inisiasi Menyusui Dini (IMD), Pemberian ASI Eksklusif kepada bayi 0-6 bulan, Selain ASI bayi diberi makanan pendamping ASI (MP-ASI) dan lanjutan pemberian ASI sampai aak usia 2 tahun atau lebih, Menjelaskan pengertian ASI Eksklusif, Menjelaskan kepada masyarakat tentang pokok-pokok peraturan pemerintah nomor 33 tahun 2012 yaitu tentang pemberian ASI Eksklusif, Menjelaskan 8 keberhasilan menyusui yaitu Ibu mengetahui manfaat menyusui, Ibu melakukan persiapan menyusui, Ibu mengetahui tentang Inisiasi Menyusi Dini, Ibu melakukan posisi menyusi dengan benar, Ibu melakukan pendekatan bayi dengan payudara dengan benar, Ibu memberikan ASI Eksklusif, Menyusu seseiring mungkin semaunya, Ibu menghindari pemberian susu formula dan Ibu menerapkan 10 pedoman gizi seimbang.

Peranan petugas kesehatan menjadi salah satu faktor yang mempengaruhi pemberian ASI eksklusif Ibu umumnya mau, patuh dan menuruti nasehat petugas kesehatan, oleh karena itu petugas kesehatan diharapkan untuk memberikan informasi tentang waktu yang tepat untuk memberikan ASI eksklusif. Manfaat ASI eksklusif dapat meningkatkan daya tahan tubuh dan resikotidak memberikan ASI eksklusif pada bayi ${ }^{11}$.

Berdasarkan salah satu faktor yang mempengaruhi motivasi ekstrinsik yaitu lingkungan, terdapat peran petugas kesehatan yang ikut andil dalammempengaruhi motivasi ibu dalam pemberian ASI eksklusif. Beberapa peran tersebut mendukung salah satu program pemerintah yakni Global Strategy for Infant and young Child Feeding. Program ini bertujuan untuk menciptakan komitmen, kepedulian, kesungguhan dan kemauan tenaga kesehatan, organisasi profesi kesehatan untuk mendukung program ASI $^{12}$

Komponen Keluaran (Output) dalam Pelaksanaan Program ASI Eksklusif di Puskesmas Olak Kemang

Output pelaksanaan program ASI Eksklusif juga diketahui dari penelitian sejenis tentang Analisis faktor external faktor internal keberhasilan program ASI Eksklusif di Puskesmas di Kota 
Pariaman yang menyatakan bahwa Cakupan pemberian ASI ekslusif di wilayah kerja Puskesmas Pariaman masih rendah, masih di bawah target yang ditetapkan oleh Dinas Kesehatan kota Pariaman. Menurut hasil penelitian yang dilakukan dengan ibu bayi di wilayah kerja Puskesmas Pariaman,hanya 1 dari 11 ibu yang memberikan ASI secara ekslusif pada bayinya. Masih banyak ibu-ibu yang memberikan makanan tambahan berupa susu formula, bubur dan roti. Salah satu strategi yang dilakukan untuk meningkatkan ASI ekslusif ini adalah dengan konseling face to face kepada ibu menyusui yang tidak memberikan ASI Eksklusif ${ }^{13}$.

\section{KESIMPULAN DAN SARAN}

Berdasarkan penelitian pada Puskesmas Olak Kemang Kota Jambi, dapat disimpulkan bahwa pelaksanaan program ASI Eksklusif di Puskesmas Olak Kemang masih kurang optimal. Hasil evaluasi pada komponen input masih kurang memadai dan komponen proces belum berjalan optimal. Hasil pelaksanaan program ASI Eksklusif belum baik terlihat dari output yang kurang baik yang belum mencapai target SPM ASI Eksklusif yaitu $80 \%$ per wilayah kerja. Adapun saran yang dapat diberikan yaitu Diperlukan komitmen dalam bentuk kebijakan pemberian ASI dan larangan pemberian susu formula, mengadakan pelatihan dan penyegaran, melakukan monitoring/ supervisi pelaksanaan konseling menyusui, membuat SOP, serta menyediakan sarana prasarana yang menunjang pelaksanaan program ASI Eksklusif.

\section{DAFTAR PUSTAKA}

1. WHO., Global strategy for infant and young child feeding the optimal duration of exclusive breasfeeding. 2015. diakses tanggal 27 September 2017.

2. UNICEF., 2013. United Nations International Children's Emergency Fun. www.unicef.org/.diakses tanggal 26 Agustus 2017.

3. Kemenkes.., PP Peraturan pemerintah no 33 tentang pemberian air susu ibu eksklusif. Jakarta: Kementerian Kesehatan RI. 2012

4. Astridya, P, Asyah, N, Lestari D \& Ummu,R. Pelaksanaan Program ASI Eksklusif di Puskesmas Kota Probolinggo. Surabaya: Badan Penelitian dan Pengembangan Kesehatan, Kementerian Kesehatan RI.Vol. (18): 267-276. 2013

5. Dian, F, Ramadhani \& Suryati,M., Analisis Faktor Eksternal dan Internal Program Peningkatan Pemberian ASI eksklusif. Padang: Jurnal Kesehatan Masyarakat Universitas Andalas. 2013. MaretSeptember;7(2).

6. DINKES., Profil Kesehatan Provinsi Jambi. Dinas Kesehatan Provinsi jambi. 2016

7. Kemenkes., Tata Cara Penyediaan Fasilitas Menyusui. Jakarta : Kementerian Kesehatan RI. 2013

8. Henry A., Motivasi Kerja, budaya organisasi dan Produktivitas masyarakat.Jakarta: Jurnal Psikologi. 2009. 2(2) :159-65

9. Ivancevich J, Konopaske, Meteson., Perilaku dan Manajemen Organisasi. Jakarta: Erlanggra., 2007. Edisi ke -7

10. Rachmawati,F \& Werdani F., Program Kelompok Peduli ASI Ibu di Surakarta. Surakarta: FKM Universitas Muhamadiyah Surakarta. 2008. 
11. Roesli, Utami., Mengenal ASI Eksklusif. Jakarta: Tribus Agriwidya.2005

12. Retnani.A., Hubungan Peran Tenaga Kesehatan dengan Motivasi dalam Pemberian ASI Eksklusif di Kabupaten Jember . Jawa Barat : Universitas Jawa Barat. 2016

13. Dian, F, Ramadhani \& Suryati,M., Analisis Faktor Eksternal dan Internal Program Peningkatan Pemberian ASI eksklusif. Padang: Jurnal Kesehatan Masyarakat Universitas Andalas. 2013. MaretSeptember;7(2). 